J. Perinat. Med. 8 (1980) 272

\section{Intrauterine malnutrition and urinary hydroxyproline excretion}

\author{
F. J. Walther, L. H. J. Ramaekers
}

Dept. of Neonatology, St. Annadal Hospital, Maastricht, The Netherlands

\section{Introduction}

Both amniotic fluid and urine of newborns contain hydroxyproline, an amino-acid related to the collagen metabolism and particularly the collagen matrix. Phases of rapid growth of the human body are accompanied by a high collagen turnover resulting in an increased excretion of hydroxyproline in the urine, whereas malnourishment and retarded growth lead to a diminished output $[11,15]$.

In normal pregnancy the total hydroxyproline/ creatinine (THP/Cr) ratio in amniotic fluid shows a rise around 15-19 weeks of gestation followed by a prolonged fall towards term [13]. This coincides with the rapid increase in length of the fetus.

Theoretically the $\mathrm{THP} / \mathrm{Cr}$ ratio in amniotic fluid might be used as a biochemical measure of assessing intrauterine growth. This was investigated in a preliminary report by BISSENDER et al. [2] showing significant lower amniotic THP values in European pregnancies with intrauterine malnourished infants in comparison with pregnancies with normally grown babies. But as there was a considerable overlap of the values, the clinical use of THP estimation without further evaluation was considered to be limited.

Because amniotic fluid is not readily available for research purposes, the first urine after birth can be used instead. This was done by Younoszal et al. [16]. They could not demonstrate significant differences in the first specimen of urine after birth in normal term infants and malnourished newborns. No data on the degree of malnourishment are available however.

\section{Curriculum vitae}

FRANS WALTHER was born in The Netherlands in 1948 and studied medicine at the university in Leiden. From 1974-1977 he worked at a rural hospital in Tanzania. Since 1977 he has been a resident in Pediatrics at the St. Annadal Hospital, University of Maastricht. Current studies deal with intrauterine malnutrition, its early diagnosis and outcome.

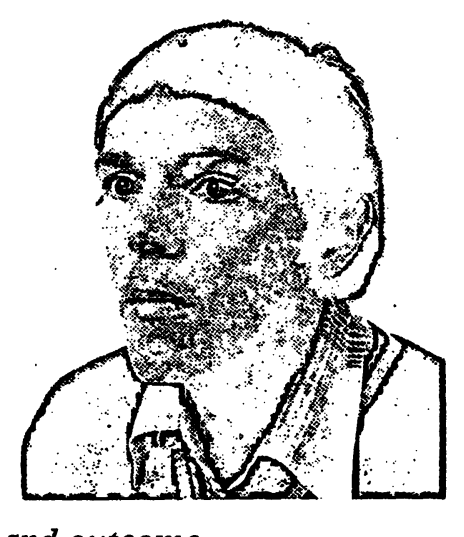

Intrauterine malnutrition is the most frequent cause of SGA, and these infants are usually recognizable clinically as being wasted and showing disproportional growth. This dissociation of weight and length can be objectively determined by the use of the Ponderal Index (P. I.) of RoHRER (100 $X$ weight in grams/(length in centimeters) ${ }^{3}$ ). By comparison of the P.I. with the 50 centile of the data of LUBCHENKO et al. [9] (arbitrarily considered as being the index of appropriate normal growth) the degree of intrauterine malnutrition can be quantified according to ROORD and RAMAEKERS [11]. Furthermore these authors concluded, that though the ponderal index can be used as a measure of malnutrition, birthweight alone is not a correct parameter for the definition of starvation. Therefore the malnourished newborn can have a weight well above the small-for-age (S. G. A.) borderline of the 10th centile and still be undernourished. 
In this study we tried to establish a correlation between the degree of intrauterine malnutrition and the THP/Cr. ratio in the first urine voided by 50 selected term newborns. This in order to find out if hydroxyproline excretion can be used as a biochemical parameter for diagnosis of intrauterine malnutrition by investigating the amniotic fluid in a later trial.

\section{Material and methods}

The patients consisted of 50 newborn singletons of both sexes and from all social classes, with a nutritional state varying from severe malnourishment to normal growth. They were born at a gestational age of 38 or more weeks. Those showing signs of wasting were admitted to the Department of Neonatology for a variety of reasons, the others were healthy newborns of the Obstetric Department. Gestational age was calculated from the first day of the last menstrual period and verified by the DuBowitz score, those showing a difference of more than one week were excluded from the study.

Excluded were non-Caucasians and infants with congenital malformations, congenital infections, chromosomal abnormalities and small-for-dates due to chronic fetal distress (5). RoHRER's ponderal index $\left(100 \times \mathrm{W} / \mathrm{L}^{3}\right)$ was determined and the deviation from "normal" ( 50 centile of the data of LUBCHENKo et al. [9]) calculated according to ROORD and RAMAEKERS [11].

Immediately after birth first urine samples were collected in plastic bags, which were emptied as soon as they contained $15 \mathrm{ml}$. of urine, a quantity always met at the first voidance. Urine was stored frozen at $-10^{\circ} \mathrm{C}$. Creatinine in the urine was determined by the classical method of Jaffé after dialysis to remove non specific chromogens of low molecular origin.

Total urinary hydroxyproline was estimated as described by GoVERDE and VEENKAMP [3], which method is in good agreement with that of PROCKOP-KIVIRIKKo [7]. The ratios of total hydroxyproline (mmol/l)/creatinine (mmol/l) were calculated. Single samples were used as YounosZAI et al. [17] and Howells et al. [6] showed a good correlation between $\mathrm{THP} / \mathrm{Cr}$. ratios in 24-hours collections and in random urine samples. 24-hour sampling seemed therefore unnecessary.

\section{Results}

In analyzing the 50 newborns proved to show a continuum of normal growth to an increasing degree of wasting whereas 3 newborns also showed postmature characteristics (CLIFFORD stages I/III).

The mean and range for weight and height are given in Tab. $I$, the distribution on the percentile charts of the RoHRER index [9] in Tab. II. Fig. 1 represents the correlation between deviation from "normal" ponderal index (50 centile for the individual gestational week) and the THP/Cr. ratio in the first urine voided after birth. No significant relationship between these two parameters could be established (all points were used in calculating the regression equation: $\mathrm{Y}=0.115-$ $0.038 \mathrm{X} ; \mathrm{r}=-0.141, \mathrm{n}=50, \mathrm{~N}$. S.). Also no correlation was found between the absolute THP values of $\mathrm{THP} / \mathrm{cr}$. ratio and weight, length and body surface at birth. Girls tended to a lower THP/Cr. ratio than boys ( 0.018 with a standard deviation of \pm 0.037 vs. $0.135 \pm 0.066$ ), though these differences were not statistically significant $(P \geqslant 0.05)$. The mean $\mathrm{THP} / \mathrm{Cr}$. ratio of the whole group amounted to 0.124 with a range of $0.040-0.331$ and a standard deviation of 0.055 .

Tab. I. Mean and range of weight and length of the study group.

\begin{tabular}{|c|c|c|c|}
\hline & $\begin{array}{l}\text { Weight } \\
\text { g }\end{array}$ & \multicolumn{2}{|c|}{$\begin{array}{l}\text { Length } \\
\mathrm{cm}\end{array}$} \\
\hline & mean range & mean & range \\
\hline Study group & $3071 \quad 1630-4130$ & 50.3 & $43.1-55.0$ \\
\hline
\end{tabular}

Tab. II. Distribution of the study group on the percentile charts of the ROHRER index.

\begin{tabular}{lc}
\hline Percentile ranges & $\begin{array}{l}\text { Number of } \\
\text { studied } \\
\text { newborns }\end{array}$ \\
\hline P 50-75 & 6 \\
P 25-50 & 17 \\
P $10-25$ & 16 \\
P $<10$ & 11 \\
Total & 50
\end{tabular}




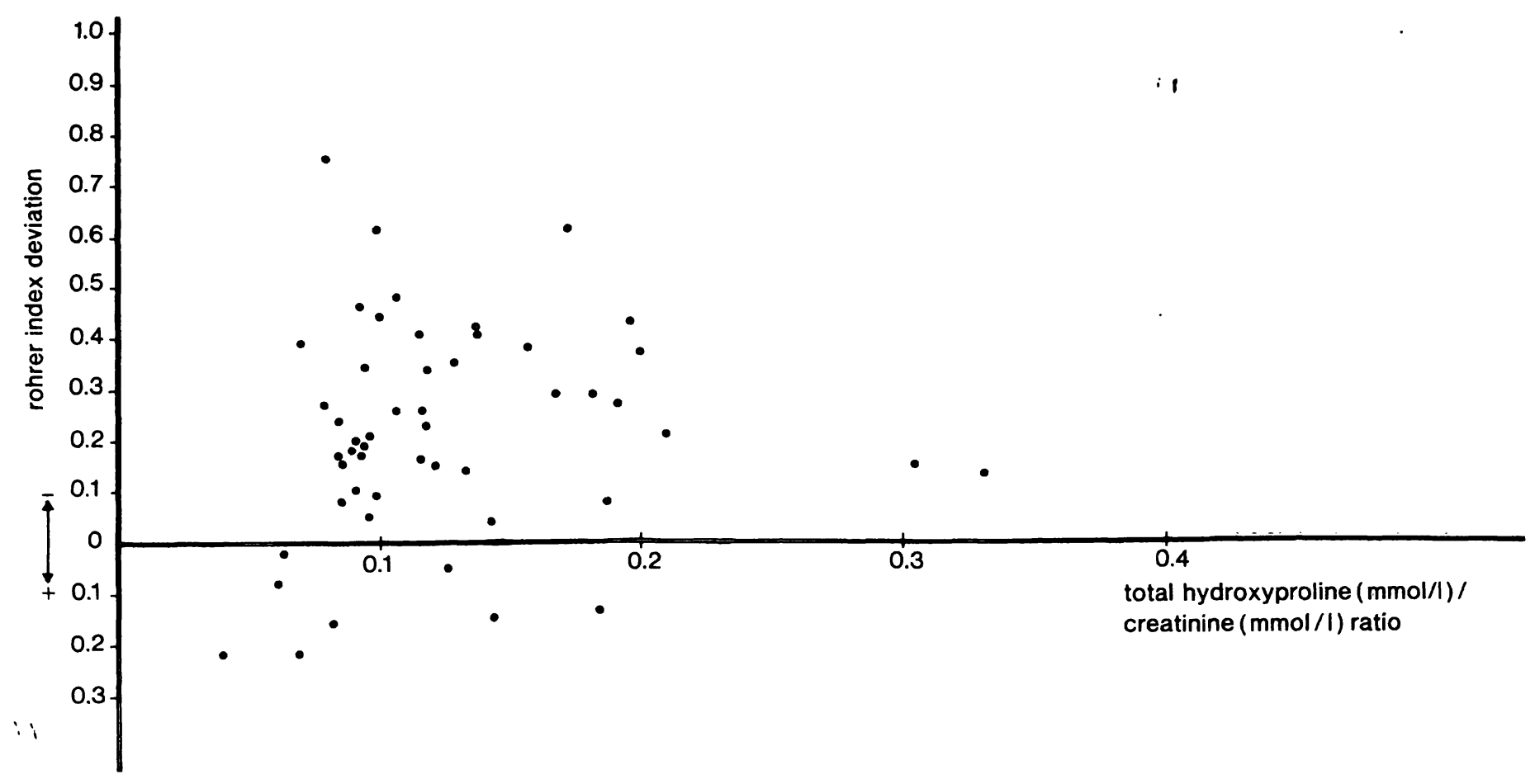

Fig. 1. Correlation between ROHRER index deviation from "normal" and total hydroxyproline (mmol/1)/creatinine (mmol/1) ratio in the first urine passed by newborns.

\section{Discussion}

The THP/Cr. ratio has been shown to be related to collagen turnover and to reflect the rate of growth in children. The largest amounts of hydroxyproline are excreted with the urine during the first three months of life. Thereafter it falls quickly till 12 months of age followed by a much slower decrease until pubertal growth spurt $[4,14]$.

The ratio of total hydroxyproline/creatinine is used instead of the absolute values of the total urinary hydroxyproline excretion because it gives more consistent results for subjects of the same biological age, as creatinine excretion is correlated with body size and muscle mass [1]. Whereas in children over 6 months of age the major portion of urinary hydroxyproline is peptide-bound and only $5 \%$ or less is in the free form, infants during the first three months of life excrete about a third of the total hydroxyproline in the free form [4].

KLUJBER et al. [8] found that premature infants, intrauterine malnourished term infants and normally grown infants excreted about the same proportion of free hydroxyproline during the first three weeks of life, which means that total urinary hydroxyproline measurements can be used in that period.

Although our values are in good agreement with the values found by YounoszaI et al. [16] we could not find any correlation between the degree of growth retardation and THP excretion. The explanation for this is probably the fact that intrauterine growth is retarded under normal circumstances in the last trimester according to GRUENWALD [5]. The normal range of urinary THP excretion being already wide, starvation does not add a measurable and significant decrease to THP excretion.

Other parameters have to be searched for, as prenatal diagnosis of intrauterine malnutrition by means of biochemical analysis of amniotic fluid seems important. More promising may be the amniotic or urinary 3-methyl-histidine excretion. This amino-acid is almost exclusively present in skeletal muscle proteins and is excreted without further metabolism or -recycling during their catabolism [10] in rats. However, the difficult quantitative estimation of this amino-acid hampers its clinical research up till now. 


\section{Summary}

The purpose of this study was to investigate if the excretion of hydroxyproline in the first urine of newborns could be used as a biochemical parameter for the diagnosis of intrauterine malnutrition preliminary to investigation of amniotic fluid. Hydroxyproline in the urine is considered a reliable index of bone collagen metabolism and correlates well with skeletal growth which is retarded in intrauterine malnutrition [12].

A precisely defined diagnosis of malnutrition and its severity is necessary first of all. In order to quantify the degree of malnutrition of newborns the deviation of the ponderal index $(100 \times$ weight in grams/(length in centimeters) ${ }^{3}$ ) from "normal" (defined as the 50 centile of the data of LUBCHENKO et al. [9]) was used. By chemical analysis the total hydroxyproline excretion in the first urine sample passed after birth was determined as well as the creatinine excretion. As creatinine excretion is correlated with body size and muscle mass, the total hydroxyproline $(\mathrm{mmol} / \mathrm{l}) /$ creatinine $(\mathrm{mmol} / \mathrm{l})$ or $\mathrm{THP} / \mathrm{Cr}$. ratio was used instead of the absolute values of the total hydroxyproline excretion as it gives more consistent results for subjects of the same biological age. Single samples of urine could be used because they show a good correlation with 24-hour collections of urine.

50 Selected normal and malnourished term infants were investigated, all were Caucasian babies without congenital malformations, congenital infections, and chromosomal abnormalities, whereas small-for-dates due to chronic fetal distress and genetically determined small-for-dates were excluded. No correlation between the degree of intrauterine malnutrition (defined as the deviation of the ponderal index from "normal growth") and the THP/Cr. ratio could be established (Fig. 1). Other studies, not defining the degree of intrauterine malnutrition, show a considerable overlap between normal and malnourished term infants. This study proves that urinary hydroxyproline excretion cannot be used clinically as a measure of intrauterine malnutrition of the newborn, probably because intrauterine growth is retarded already under normal conditions in the last trimester [5]. The normal range of urinary hydroxyproline excretion being already wide, starvation does not add a measurable and significant decrease to the hydroxyproline excretion.

Keywords: Intrauterine malnutrition, ponderal index, term newborns, urinary hydroxyproline/creatinine excretion.

\section{Zusammenfassung}

Intrauterine Mangelernährung und Hydroxyprolinausscheidung im Urin

Uns interessierte, ob die Hydroxyprolinmenge im ersten Urin des Neugeborenen als biochemischer Indikator einer intrauterinen Mangelernährung gewertet werden kann als Vorarbeiten hinsichtlich der Fragestellung, ob Hydroxprolinbestimmungen im Fruchtwasser eine Aussagekraft haben. Die Hydroxyprolinausscheidung im Urin ist ein Maß für den Kollagenstoffwechsel im Knochengewebe und korreliert mit dem Skelettwachstum, welches bei intrauteriner Mangelernährung retardiert ist [12]. $\mathrm{Zu}$ nächst muß eine exakte Diagnose der Mangelernährung bzw. ihres Ausmaßes getroffen werden. Um den Grad der Mangelemährung bei den Neugeborenen zu quantifizieren, wurde die Abweichung des Gewichtsindex $(100 \times \mathrm{Ge}-$ wicht in Gramm/(Länge in $\mathrm{cm})^{3}$ ) vom „Normalindex “ (gemessen an der 50er Perzentile nach LUBCHENKO et al. [9]) bestimmt. In der ersten Urinprobe des Neugeborenen wurden sowohl der Hydroxyprolin- wie auch der Creatiningehalt gemessen. Da die Creatininausscheidung mit der körperlichen Konstitution und der Muskelmasse korreliert, wurde ein Quotient aus Gesamthydroxyprolinkonzentration $(\mathrm{mmol} / \mathrm{l})$ und Kreatininkonzentration (mmol/l) gebildet. Damit eliminieren wir Fehlermöglichkeiten, die durch ein unterschiedliches biologisches Alter der Neugeborenen bedingt sind. Wegen der guten Korrela- tion zwischen 24-h-Sammelurin und den einzelnen Urinproben konnten auch letztere als Meßproben verwendet werden. Das Untersuchungskollektiv bestand aus 50 ausgewählten normalen und mangelernährten Neugeborenen, die am Termin entbunden worden sind. Die Kinder hatten weder kongenitale Mißbildungen und Infektionen noch Chromosomenanomalien. Lag bei den Small-for-dateBabies als ätiologischer Faktor eine chronische fetale Beeinträchtigung oder eine genetische Anomalie zugrunde, wurden sie aus unserem Kollektiv ausgeschlossen.

Wir fanden keine Korrelation zwischen dem Grad der Mangelernährung (definiert als Abweichung des Gewichtsindex vom Normalwert) und dem Gesamthydroxyprolin/ Kreatinin-Quotienten (Fig. 1). Läßt man die unterschiedliche Ausprägung der Mangelernährung unberücksichtigt, so zeigt sich eine beträchtliche Überlappung zwischen den Kurven normaler und mangelernährter Kinder. Unsere Untersuchung beweist, daß die Hydroxyprolinausscheidung im Urin klinisch nicht als Maß für eine intrauterine Mangelernährung angesehen werden kann. Wahrscheinlich ist schon unter normalen Bedingungen das intrauterine Wachstum im letzten Trimester reduziert [5]. Die Hydroxyprolinausscheidung im Urin unterliegt großen Schwankungen und die Mangelversorgung scheint keinen signifikanten bzw. meßbaren Abfall der Hydroxyprolinausscheidung zur Folge zu haben.

Schlüsselwörter: Gewichtsindex, Hydroxyprolinausscheidung, Kreatininausscheidung, intrauterine Mangelernährung, Neugeborenes. 


\section{Résumé}

Malnutrition intrauterine et excrétion urinaire d'hydroxyproline

L'objet de cette étude était de déterminer si l'excrétion d'hydroxyproline dans les premières urines du nouveau-né peut être considérée comme un paramètre biochimique dans le diagnostic de malnutrition intrautérine, avant l'examen du liquide amniotique. L'hydroxyprolinurie est considérée être un indexe fiable du métabolisme collagène osseux et correspond bien au poids squelettique qui est en retard en cas de malnutrition intrautérine [12]. Il est avant tout nécéssaire de définir le diagnostic de malnutrition ainsi que sa gravité. Afin de définir quantitativement le degré de malnutrition des nouveaux-nés nous avons utilisé l'indexe de déviation pondérale $(100 \times$ le poids en $\mathrm{g}$./(longueur en $\mathrm{cm}$.) ${ }^{3}$ ) du "normal“ (défini comme comme le 50 centile de la valeur de LUBCHENCO et coll. [9]. L'excrétion totale d'hydroxyproline dans le premier échantillon d'urine obtenu ainsi que l'excretion de créatinine ont été déterminées par méthode chimique. Comme l'excrétion de créatinine est liée au poids corporéal et à la masse musculaire, nous avons utilisé le rapport hydroxyproline totale $(\mathrm{mmol} / \mathrm{l}) /$ créatinine $(\mathrm{mmol} / \mathrm{l})$ ou encore THP/Cr àu lieu des valeurs absolues d'hydroxyproline totale, car œ rapport livre des résultats plus significatifs pour des sujets de même âge biologique. Des échantillons isolés d'urine pouvaient être utilisés puisqu'ils montraient une bonne corrélátion avec les valeurs dans l'urine de 24 heures.

Nous avons examiné 50 enfants normaux et malnourris à terme; il s'agissait de bébés Caucasiens exempts de malformations congénitales, d'infections congénitales, d'abérrations chromosomiques, alors que nous avons exclus de l'étude les dystrophes par souffrance foetale chronique ou bien pour cause génétique. Il n'a pas été observé de corrélation entre de degré de malnutrition intrautérine (défini comme la déviation de l'indexe pondéral du "poids normal ") et le rapport $\mathrm{THP} / \mathrm{Cr}$. (fig. 1). D'autres études, ne définissant pas le degré de malnutrition intrautérine, montrèrent un considérable chevauchement entre enfants normaux èt malnutris à terme. Cette étude montre que l'excrétion d'hydroxyproline dans l'urine ne peut guère être ulisée en clinique pour l'appréaciation d'une malnutrition intrautérine du nouveau-né, probablement parce-que la croissance intrautérine est déja même normalement ralentie au cours du dernier trimestre [5]. La variabilité de l'hydroxyprolinurie étant déja grande, la malnutrition n'ajoute point de diminution mesurable et significative de l'exćretion d'hydroxyproline.

Mots-clés: Indexe pondéral, malnutrition intrautérine, nouveauxnés à terme, rapport hydroxyprolinurịie/excrétion de créatinine.

\section{Bibliography}

[1] Allison, D. J., A. WALkER, Q. T. SMIth: Urinary hydroxyproline: Creatinine ratio of normal humans at various ages. Clin. Chim. Acta 14 (1966) 129

[2] BISSENDER, J. G., P. SCOTT, B. A. WHARTON: Assessment of nutrition status of the fetus by examination of amniotic fluid. Arch. Dis. Childh. 53 (1978) 263

[3] GOVERDE, B. C., F. J. N. VEENKAMP: Routine assay of total urinary hydroxyproline based on resincatalysed hydrolysis. Clin. Chim. Acta 41 (1972) 29

[4] GRAF, U., M. VEST: Zur normalen Hydroxyprolinausscheidung im Urin bei Säuglingen, Kindern und Adoleszenten. Z. Kinderheilk. 110 (1971) 128

[5] GRUENWALd, P.: Pathology of the deprived fetus and its supply line. In: Size at birth. 27th Ciba Fdn. Symp. 3-26 (1974)

[6] Howells, G. R., B. A. Wharton, R. A. MCCANCE: Value of hydroxyproline indices in malnutrition. Lancet I (1967) 1082

[7] KIVIRIKKO, K. I., O. LAITINEN, D. J. PROCKOP: Modification of a specific assay for hydroxyproline in urine. Anal. Biochem. 19 (1967) 249

[8] KLUJBeR, L., J. MESTYÁN, E. SULYOK, G. SOLTÉSZ: Urinary hydroxyproline excretion in normally grown and growth-retarded newborn infants. Biol. Neonate 20 (1972) 196
[9] LUBCHENKO, L. O., C. HAUSMAN, E. BOYD: Intrauterine growth in length and head circumference as estimated from live births at gestational ages from 26 till 42 weeks. Pediatrics 37 (1966) 403

[10] NAGABHUSHAN, V. S., B. S. RAO: Metabolism of 3-methyl histidine in experimentally induced protein-energy malnutrition in rats: Urinary excretion and muscle content of 3-methyl histidine. Life sciences 18 (1976) 639

[11] ROORD, J. J., L. H. J. RAMAEKERS: Quantification of intra-uterine malnutrition. Biol. Neonate 33 (1978) 273

[12] ROORD, J. J., L. H. J. RAMAEKERS, J. M. A. VAN ENGELSHOVEN: Intra-uterine malnutrion and skeletal retardation. Biol. Neonate 34 (1978) 167

[13] WHARTON, B. A., J. W. FOULDS, I. D. FRASER, C. A. PENNOCK: Amniotic fluid total hydroxyproline and intrauterine growth. J. Obstet. Gynec. Brit. Cwlth. 78 (1971) 791

[14] WhaRton, B. A., G. GoUgh, A. Williams, S. KITTS, C. A. PENNOCK: Urinary total hydroxyproline: Creatinine ratio range of normal and clinical application in British children. Arch. Dis. Childh. 47 (1972) 74

[15] WHITEHEAD, R. G.: The assessment of nutritional status in protein-malnourished children. Proc. Nutr. Soc. 28 (1969) 1 
[16] YOUNOSZAI, M. K., J. C. HAWORTH: Excretion of hydroxyproline in urine by premature and normal full-term infants and those with intrauterine growth retardation during the first three days of life. Pediat. Res. 2 (1968) 17
[17] YounOSzAl, M. K., A. KACIC, L. DILlinG, J. C. HAWORTH: Urinary hydroxyproline: Creatine ratio in normal pre-term and growth-retarded infants. Arch. Dis. Childh. 44 (1969) 517

Received April 16, 1980. Accepted July 7, 1980.

Dr. F. J. Walther Dept. of Neonatology St. Annadal Hospital P. O. Box 1918 NL-6201 BX Maastricht The Netherlands 